\title{
NARRATIVAS EN EL PAÍS DE LA INFANCIA
}

\author{
NARRATIVES IN THE LAND OF CHILDHOOD
}

Leonor Arfuch

Universidad de Buenos Aires

Buenos Aires, Argentina

\section{Resumen}

La expresión de la propia subjetividad, tanto en los medios de comunicación como en la política, la investigación académica, la literatura, el cine y las artes visuales, tuvo sin duda un anclaje prioritario en la instauración de la memoria pública como un deber ético en las sociedades contemporáneas, y por ende en la valorización del testimonio, en sus formas más diversas, como un modo de dar cuenta de la experiencia de pasados traumáticos, donde las memorias de la segunda guerra y de la Shoá dejaron una matriz indeleble. En esa herencia testimonial, en estos avatares del espacio biográfico, se inscriben las narrativas a las que alude el título de mi artículo, que anudan los tres significantes que lo presiden: infancia, memoria, autoficción. Son narrativas de autores - escritora y cineastas - que padecieron el hecho común de vivir la infancia en dictadura - la última dictadura militar en la Argentina, 1976-1983 - y ser víctimas directas de ella, confrontadas, en una lectura sintomática, con otras narrativas, singulares, de nińos cuando eran niños, recogidas por un periodista en el retorno a la democracia y publicadas en un libro mucho tiempo después. Mientras los primeros decidieron afrontar la elaboración narrativa de sus memorias traumáticas a través de la creación de obras autoficcionales, las voces de los niños, registradas en esa primeridad de la experiencia, dejaron un conmovedor testimonio de inocencia y miedo.

Palabras-clave: Narrativas; infancia; memoria; autobiografía; autoficción.

\section{Abstract}

The expression of one's own subjectivity, whether in the media or in politics, in academic research or in literature, film, and the visual arts, certainly found a priority grounding as part of the establishment of public memory as an ethical duty in contemporary societies, and in the subsequent valuation of testimony, in its various forms, as a means to account for the experience of traumatic pasts, where memories of World War II and of the Shoah left an indeli-

\section{Resumo}

A expressão da própria subjetividade, tanto nos meios de comunicação quanto na política, na pesquisa acadêmica, na literatura, no cinema e nas artes visuais, teve sem dúvida uma ancoragem prioritária na instauração da memória pública como um dever ético nas sociedades contemporâneas, e por consequência na valorização do testemunho, em suas formas mais diversas, como um modo de dar conta da experiência de passados traumáticos, entre os quais as memórias da

\footnotetext{
${ }^{1}$ Este trabajo fue, en su primera versión, la conferencia inaugural del Coloquio Internacional En el país del Nunca Jamás: Narrativas de infancia en el Cono Sur, organizado por el Instituto de Estética de la Pontificia Universidad Católica de Chile, los días 2 y 3 de octubre de 2013.
} 
ble mark. It is in the context of this testimonial heritage, in these iterations of the biographical space that the narratives to be analyzed here are inscribed; narratives which tie together the three signifiers that preside over it: childhood, memory, and auto-fiction. They are narratives by some authors -writer, filmmakers- who have suffered the shared fact of having lived their childhood under a dictatorship - the last military dictatorship in Argentina, 1976-1983 - and of having been its direct victims, confronted, in a symptomatic reading, with another singular narratives by children when they were children, recorded by a journalist at the return of democracy and published in a book long time after. While the first ones decided to tackle the narrative development of their traumatic memories by creating a kind of fictional autobiographical works, the voices of "real children" leaved a moving testimony of innocence and fear.

Keywords: Narratives; childhood; memory; autobiography; autofiction. segunda guerra e da Shoah deixaram uma matriz indelével. Nessa herança testemunhal, nesses avatares do espaço biográfico, se inscrevem as narrativas às quais alude o título desse artigo, que unem os três significantes que o presidem: infância, memória, autoficção. Sua narrativa de autores - escritora e cineastas - que padeceram o feito comum de viver a infância na ditadura - a última ditadura militar na Argentina, 1976-1983 - e ser vítimas diretas dela, confrontadas, em uma leitura sintomática, com outras narrativas, singulares, de crianças quando eram crianças, recolhidas por um jornalista na volta à democracia e publicadas em um livro muito tempo depois. Enquanto os primeiros decidiram afrontar a elaboração narrativa de suas memórias traumáticas através da criação de obras autoficcionais, as vozes das crianças, registradas nessa primeira idade da experiência, deixaram um comovedor testemunho de inocência e medo.

Palavras-chave: Narrativas; infância; memória; autobiografia; autoficção.

\section{Nunca recobramos nuestra infancia, ni el ayer tan próximo ni el instante huido al instante.}

E. BENVENISTE

Jamás podremos rescatar del todo lo que olvidamos. Quizá esté bien así. El choque que produciría recuperarlo seria tan destructor que al instante deberiamos dejar de comprender nuestra nostalgia. Walter BENJAMIN, Infancia en Berlin hacia 1900.

La infancia ha sido siempre un territorio privilegiado para la literatura, tanto en sus andares biográficos como ficcionales, poéticos y hasta filosóficos, de Proust a Benjamin, para tomar sólo dos hitos emblemáticos. Y si bien, como decía Benveniste, "nunca recobramos nuestra infancia" el retorno a ese tiempo cercano o lejano, fantaseado o fantasmático, forma parte indisociable de nuestra experiencia. Allí anidan claves que dejan su impronta en el devenir -sin condicionarlo en términos absolutos- y también un núcleo resistente de nostalgia que involucra los seres y las cosas. Un retorno traído 
por la memoria involuntaria -Proust- o por el trabajo de la rememoración -la anamnesis-, que puede desplegarse en la temporalidad de un relato articulado, atento a la sucesión de aconteceres - la novela, la autobiografía- o en "iluminaciones", a la manera de Benjamin, esas briznas del recuerdo ligado a imágenes entrañables -las tías que esperan con la mesa servida para el té, la franja de luz debajo de la puerta del dormitorio de los padres que anuncia la partida de un viaje inminente (BENJAMIN, 1990). Infancia y memoria parecen así enlazarse en una relación particular, donde la imagen evocada se plasma en el presente de la enunciación trayendo consigo una carga afectiva que lo transfigura: como toda memoria, es siempre presente. Y ese volver sobre la infancia no es inocuo, hay allí una búsqueda de sentidos que se enfrenta a menudo con imágenes de contorno incierto - ¿recordamos escenas o fotografías, lo hemos vivido o nos lo han contado? - vacilaciones que confirman, una vez más, que nuestra vida no nos pertenece por entero y que nuestra historia, sobre todo en esa primeridad de la existencia, se entrama en la mirada y la palabra de los otros.

También, ante el relato autobiográfico, se plantea la pregunta clásica: ¿Quien habla allí? ¿El adulto que es hoy, el que recuerda, no sin nostalgia, un tiempo irremediablemente perdido? ¿El/la que pretende remontar el tiempo y recuperar esa fresca vivencia, "algo que se destaca del flujo de lo que desaparece en la corriente de la vida” (GADAMER, 1977: 96) desde una especie de autoficción? (ARFUCH, 2002) ¿Y qué infancia aparece en el recuerdo? ¿La de un tiempo feliz, la levedad del juego y los afectos, los veranos, la casa paterna, el entorno familiar? ¿La de los miedos y desvelos nocturnos, el temor al abandono, a la pérdida de los seres queridos? ¿La combinación entre ambas, como visión equilibrada de la "normalidad"? ¿O aquella infortunada, transcurrida en un estado de excepción, sin la idílica postal familiar? ¿Y qué sucede cuando el estado de excepción deviene cotidiano, cuando el miedo se transforma en un modo de vida - "vivir en el miedo"- , cuando la pérdida brutal acontece como si fuera un hecho necesario? ¿Qué queda como marca de esa traumática experiencia?

A partir de estas preguntas se define el tema de mi artículo, que podría resumirse tentativamente en un sintagma abstracto e inclusivo: la infancia en dictadura, tema que abordaré, como es imaginable, desde la experiencia argentina, ${ }^{2}$ o mejor, desde ciertas narrativas que responden de maneras diversas a

\footnotetext{
${ }^{2}$ Me refiero obviamente a la cruenta experiencia de la última dictadura cívico-militar en la Argentina (1976-1983), que dejara miles de muertos y desaparecidos, ejerciendo una violencia represiva inédita tanto en combate contra una guerrilla ya francamente desarticulada y fundamentalmente contra toda militancia política, barrial o sindical, como en campos de concentración y centros clandestinos de detención -tortura, violación, abducción de niños, delitos contra la propiedad y abusos de toda índole.
} 
esas preguntas trazando sin embargo una línea común. El corpus comprende dos películas, Infancia clandestina, de Benjamín Ávila (2011) y El premio, de Paula Markovitch (2011), una novela autobiográfica, La casa de los conejos, de Laura Alcoba (2010), una tesis sobre la revista infantil Billiken, publicada precisamente bajo el título La infancia en dictadura, de Paula Guitelman (2006) y un libro singular, ¿Cómo es un recuerdo?, de Hugo Paredero (2007), que recoge las respuestas de 150 niños de 5 a 12 años en entrevistas realizadas por él con un cuestionario abierto apenas recuperada la democracia, en 1984.

¿Por qué este recorte? Pese a que toda selección de un universo tiene un alto grado de arbitrariedad -siempre son posibles otros agrupamientosme animaría a responder, tomando una feliz expresión de Tununa Mercado: porque traduce elocuentemente un "estado de memoria" en mi país, a más de 30 años del retorno a la democracia, una fecha que cabe celebrar. Y digo un "estado de memoria" porque no es, por cierto, el único.

\section{Avatares de la memoria}

Si aceptamos que hay temporalidades de la memoria, cosas que requieren un tiempo para poder mostrarse a la luz, ser aceptadas, entrar en el debate público, el tiempo transcurrido marca un crescendo en cuanto a la aparición de múltiples voces y una notoria diversificación de las temáticas. Después del primer momento, el de las víctimas, los deudos, los testigos, donde el testimonio de lo padecido fue a la vez prueba para la justicia y elaboración catártica del trauma, se fueron sucediendo innúmeros relatos donde campeaba la narrativa vivencial: biografías, autobiografías, testimonios, memorias, correspondencias, relatos de vida, poemarios, entrevistas, diarios de cárcel, confesiones, conversaciones. Con el tiempo, y sin perder nunca la carga testimonial, fue apareciendo en ese espacio subjetivo la autoficción, un género híbrido, a veces cercano a la novela, donde la marca autobiográfica se diluye en la tercera persona o en otro personaje sin pretensión de una "verdad" referencial. Esa apertura coincidió en algunos casos con la irrupción de voces donde el lugar de la víctima dejaba paso a otros protagonismos: el de los exiliados, los guerrilleros y otros militantes - categorías por cierto no excluyentes. Asimismo, la ficción lisa y llana -en la novela, el cine, el teatro, la televisión - introdujo nuevos puntos de vista -y un reparto de la palabra,- tanto como la investigación periodística y académica, que aportó un enorme caudal de conocimiento a la escena constructiva de la memoria: análisis sociológicos, culturales, históricos, políticos, resultados de trabajo de campo, estudios narrativos, debates intelectuales, etcétera. Por cierto, el registro de la visualidad no fue ajeno a este proceso: las artes visuales -o prácticas artísticas, como se prefiera- 
constituyeron y siguen constituyendo un campo privilegiado de experimentación (ARFUCH, 2013).

Llegado un momento, en ese horizonte multifacético comenzó a producirse un giro generacional: el tiempo de los hijos. Los de los desaparecidos, inquisidores, buscadores de indicios, de huellas a menudo arqueológicas algunos, orgullosos de esos padres que conocieron poco o que no alcanzaron a conocer, otros dolidos, hasta acusadores, por la vida ofrendada a una causa antepuesta a su rol familiar- y también otros hijos, sus contemporáneos, cuyas vidas bajo la dictadura transcurrieron en aparente normalidad pero cuyas preguntas irrumpen asimismo en el espacio dialógico con una marca inequívoca. Si los primeros centran su inquietud en la historia de sus padres, tratando de aprehender sus contornos, la difícil relación entre vida cotidiana y militancia -algunos, hurgando en sus propios recuerdos de pequeños, cuando los acompañaban en ese trajinar- y de comprender las razones, políticas e ideológicas de su compromiso, los segundos se enfrentan, quizá más desprevenidamente, a otro tipo de curiosidad: ¿Cómo era vivir en dictadura? ¿Qué sabían (o no sabían) sus padres? ¿Y qué hicieron con ese saber? Interrogantes que, aún formulados en el ámbito doméstico, envueltos en recuerdos de la infancia, rondan sin embargo el dilema de la Historia con mayúscula: ese pasaje conflictivo que va del "¿por qué? al "porque...” (RICOEUR, 2004).

La voz pública de hijos de desaparecidos - por sobre el silencio desolador de los hijos apropiados, aún no encontrados, algunos de los cuales seguramente intuyen y temen la revelación, otros quizá ni siquiera sospechan cuál puede ser su verdadera identidad $-{ }^{3}$ introdujo un matiz diferencial en el ejercicio de la memoria y en la indagación histórica del pasado. Están los que asumieron la militancia en derechos humanos a través de la creación de la agrupación H.I.J.O.S ${ }^{4}$-que hizo célebre la figura del "escrache", como una

\footnotetext{
${ }^{3}$ Entre los crímenes de lesa humanidad perpetrados por la dictadura argentina se encuentra la apropiación de nińos pequeños secuestrados durante los operativos que irrumpían en las casas de familia para llevarse a sus padres y la de bebés nacidos en cautiverio, que eran entregados ilegalmente a familias sustitutas, borrando toda huella de su verdadera identidad. La ciclópea tarea de las Abuelas de Plaza de Mayo, agrupación fundada en tiempos de la dictadura (1977), consiste justamente en la búsqueda y recuperación de esos "nietos" para restituirles su identidad biológica y su historia, una tarea detectivesca, de búsqueda de indicios y confrontación de archivos, donde se han ido recolectando muestras de ADN de los familiares concernidos para conformar un Banco de datos genéticos que es modelo en su género en el mundo. Hay jóvenes que se acercan voluntariamente a dejar su muestra para ser confrontada en el Banco porque tienen alguna sospecha de no ser hijos legítimos de esos padres (que los anotaron como propios) y otros a quienes se los busca gracias a testimonios, documentos, archivos o denuncias y en ese caso tienen que dar alguna muestra de su ADN por ley. Hasta el momento se ha logrado restituir su identidad a 119 "nietos" de un número estimado de alrededor de 500 nińos que corrieron tal suerte.

${ }^{4}$ La agrupación H.I.J.O.S., acrónimo de Hijos e Hijas por la Identidad y la Justicia contra el Olvido y el Silencio, fue fundada en 1994 con el objeto de nuclear principalmente a hijos de desaparecidos y
} 
intervención urbana y vocinglera para denunciar la tranquila vecindad de antiguos represores ante sus propias puertas- y los que se sumaron a las Madres y Abuelas de Plaza de Mayo o a otros organismos existentes. Algunos adquirieron notoriedad como artistas, llevando su búsqueda filial al plano estético. Entre estos últimos, varios eligieron el cine como modo de expresión, en el contexto, justamente, de lo que se ha dado en llamar "el nuevo cine argentino". Valgan como ejemplo, formalmente disímil, tres películas emblemáticas que han sido ampliamente comentadas, Papá Iván, de María Inés Roqué (2000), un documental subjetivo que intenta reconstruir la figura paterna un dirigente guerrillero muerto en combate-con el aporte prioritario de testimonios; Los rubios, de Albertina Carri (2003), que renuncia expresamente a esa modalidad narrativa y se inclina hacia una suerte de autoficción, mostrando las grietas de lo irrecuperable -en su caso, ambos progenitores-; y $M$, de Nicolás Prividera (2007), cuestionadora y crítica del entorno político y social en el cual su madre fue desaparecida, que aparece como una búsqueda de los por qué. Otra hija, Lucila Quieto, artista visual, exploró las posibilidades de la fotografía en una impactante instalación, Arqueología de la ausencia (2001), donde se fotografió ella misma sobre diapositivas ampliadas de su padre -a quien no conoció- proponiendo una inquietante simultaneidad, un ensayo identitario que luego repitió con las fotografías de otros hijos e hijas que quisieron compartir la experiencia.

En ese diálogo con nuevas voces (los sobrevivientes/los descendientes) lo auto/biográfico sigue siendo prioritario aunque adquiere obligadamente otros acentos. Ya no se trata de dar cuenta de la experiencia del pasado en términos de la más rotunda presencia -el cuerpo propio sometido a tortura, vejación, persecución-, se trata justamente de hacer presente la ausencia como dato esencial de la identidad, de hacer de la afirmación pública de la filiación -como búsqueda incierta, como protesta o como rebeldía- un gesto político. Diversas posiciones se reconocen en este espacio biográfico donde el estado de excepción aparece interrumpiendo un cauce de memorias cotidianas. La intimidad perdida de la infancia -buscada, fantaseada, escamoteada, como lo muestran los muñequitos Playmobil animados de Albertina Carri en una escena desoladora [pierde a sus padres a los 4 años]-, el arrebato de esa rutina hogareña que asegura el autorreconocimiento, es uno de los motivos más recurrentes en la evocación: el misterio de la desaparición súbita o su violencia -en el caso de quienes la presenciaron-, las preguntas a los familiares con tiempo dilatado de respuesta o sin ella, la mirada fija en la ventana esperando un retorno imposible, cada relato traza sus figuras en un fondo

ofrecer un ámbito compartido para la elaboración de sus duelos y sus historias, ayudar a la búsqueda de hermanos apropiados y a la identificación de represores que no hubieran sido aún condenados. 
común y busca, de distintas maneras, sus respuestas. Más allá de las coordenadas de la coyuntura política -que también están presentes- es la cualidad del "ser común" la que aparece a menudo enfatizada, los rasgos de carácter, los sueños, proyectos e ilusiones de quienes tenían en aquel tiempo su misma edad o eran incluso más jóvenes. En este sentido, la voz de los hijos es a la vez memoria proyectiva e interpretación del pasado pero con un fuerte anclaje en el presente, donde el trabajo de duelo -al que aporta la creación artísticaparece ganar terreno a la melancolía.

Esa desarticulación de los vínculos familiares, esa intrusión en el corazón del hogar llevada a un extremo trágico con la apropiación de los hijos una fisura irreparable en la vivencia colectiva de la identidad- es lo que hace determinante en esta historia el peso de las genealogías. Perder padre y madre repentinamente como en tantos casos, quedar a la intemperie -afectiva, explicativa, si no material- no es algo tan corriente cuando afuera, en la ciudad, en el mundo circundante, todo parece un devenir normal -no hay pilas de escombros como en los bombardeos de la guerra, ni una población sitiada, ni una catástrofe natural. Por eso tal vez no sea tan sencillo para esos hijos deslindar el reconocimiento a la convicción de las ideas y la valentía para defenderlas de la infausta suerte corrida por los padres. O, dicho de otro modo, hacer primar el perfil combativo de la figura del o la militante-que emerge, nítida, en muchos relatos de sobrevivientes- por sobre la falta de un miembro irremplazable en la trama familiar.

Es después de esa indagación sobre los padres que la mirada se torna hacia la propia infancia en dictadura y aquí aparecen, en una innegable sintonía, las tres obras de ficción que componen mi corpus: La casa de los conejos en 2010, Infancia clandestina y El premio en 2011. Y aparecen precisamente en un horizonte de debates donde nada está saldado y donde algunas voces, aun desde el progresismo, creen llegado el tiempo de un aquietamiento de la justicia, de los relatos- en mor de una hipotética "reconciliación". Este giro hacia la infancia viene a mostrar justamente que nunca habrá un fin de los relatos en la experiencia traumática de un colectivo, por más que ciertas voluntades o los mecanismos complejos de la vida política pretendan desactivar en algún caso esa perseverancia del pasado.

\section{Lo biográfico, lo memorial}

Dije tres obras de ficción aunque las tres tienen un fuerte anclaje autobiográfico: narran una historia que los tuvo como protagonistas. Pero justamente la ficción se les impuso como el único modo posible de aproximarse a ese nudo existencial: la distancia necesaria -el ponerse "afuera", según reza 
la famosa exotopía bajtiniana (BAJTÍN, 1982)-, la aceptación de la fragilidad del recuerdo y sobre todo el trabajo poético de la lengua -en el caso de Laura Alcoba- y de la imagen, en el caso de las películas, brindaron un cobijo, tanto estético como afectivo, para poder hablar.

Porque hay de qué cobijarse: las tres historias narran justamente la sensación de intemperie, la desprotección de la vida en clandestinidad, el peligro constante, el acecho cotidiano, el miedo a cometer el menor error, el miedo, simplemente, como forma de vida: "Vivir en el miedo" dice la niña de La casa de los conejos. Hijos de militantes que alternaban el vivir con los abuelos, vivir en otros países, vivir con uno de los padres, vivir escondidos o en casas transitorias, obligados a mantener el secreto de esas casas y también el de su propio nombre, nińos criados como adultos, con la carga de la responsabilidad a edades muy tempranas, niños enfrentados al uso de las armas y a las noticias de muerte o desaparición...Una experiencia de maternidades y paternidades fuera de lo común, que ha sido abordada críticamente desde diversas perspectivas pero que no es el caso analizar aquí.

Me interesa más bien ese trabajo de la ficción desde la mirada de quienes tienen hoy mayor edad que sus padres o madres y habitan un mundo radicalmente diferente. La talla del lenguaje podríamos decir -incluyendo por cierto a la imagen-, que nos pone en sintonía con la vivencia de sus personajes. La niña de La casa de los conejos, por ejemplo, que a los siete años va a vivir con su madre a una casa que comparten con otros militantes, entre ellos Diana, una mujer embarazada, donde se está armando la imprenta clandestina que edita el periódico Evita Montonera y cuya fachada es, justamente, la de un criadero de conejos. Una casa que Laura y su madre tienen la fortuna de abandonar para salir del país antes de que suceda allí una verdadera tragedia: el asalto de un cuerpo de ejército que literalmente la bombardea, matando a todos sus ocupantes, asalto al que solo sobrevive una beba de meses puesta a resguardo bajo un colchón, que es apropiada -según testimonio de vecinos- y a quien su abuela, Chicha Mariani, miembro fundadora de Abuelas, todavía está buscando. La casa, en el estado en que quedó, fue recuperada y es hoy un sobrecogedor lugar de memoria que lleva el nombre de esa beba, la "Casa Anahí". 5

Escrita en presente, con anclajes temporales que hacen honor a los famosos deícticos de Benveniste -hoy, ayer, mañana, hace dos o tres meses...- y al mismo tiempo poniendo en perspectiva el pasado en un desdoblamiento del yo narrativo -entre la nińa y la adulta- logra una sorprendente alternancia entre esa proximidad del recuerdo en sus acentos propios -la tempora-

\footnotetext{
${ }^{5}$ La Casa Anahi se encuentra en la ciudad de La Plata, capital de la Provincia de Buenos Aires. Laura Alcoba efectivamente logró reunirse con su madre en París, donde vive actualmente, y la novela fue originalmente escrita en francés.
} 
lidad de la novela, su suspenso, la voz de la niña, su mirada- y la distancia que impone el testimonio. Es notable también el trabajo sobre esa mirada imaginamos que así debió ser, los ojos desorbitados ante cada escena: el altillo, donde estaban las armas, el "embute", una palabra clave que señalaba la doble pared que escondía la imprenta, la carga de periódicos en una camioneta, envueltos con mońos de regalo. La mirada que se eleva hacia los mayores, plena de interrogantes pero también informada de un saber excesivo: "Ya soy grande, tengo 7 ańos". Una mirada donde ha quedado el recuerdo de la dulzura de los ojos de Diana, la madre de Clara Anahí -a quien Laura dedica su libro-, en medio de una férrea disciplina del no mirar, no hacerse ver, no dejar ver, que la lengua poética traduce en el cerrar de los ojos de la niña achatando el tiempo y el espacio:

Es un día de mucho sol, pero el sol me molesta y cierro los ojos.

Lo que me gusta de fruncir los párpados en estos baños de luz es que empiezo a percibir las cosas de manera muy diferente. Me gusta sobre todo el momento en que el contorno de las cosas se desdibuja y comienza a perder volumen. (...) Por la presión de mis párpados puedo hacer que el mundo retroceda, y a veces, incluso aplastarlo contra ese fondo luminoso. (ALCOBA, op. cit: 20)

Juan, el protagonista de Infancia clandestina, a quien sus padres cambian el nombre por el de Ernesto cuando regresan del exilio para la "contraofensiva" decretada por Montoneros en $1979,{ }^{6}$ tiene 12 años, una hermanita bebé y vive en una casa suburbana con sus padres, que distribuyen armas y proyectiles envasados en cajas de maní con chocolate, otra de las "fachadas" de la vida clandestina. Una madre militante de armas tomar, que aparece en toda la fiereza de su convencimiento pero también en el costado amoroso del lazo filial -en quien Benjamín Avila, el director, rinde homenaje a su madre desaparecida- aporta una tonalidad diferente a una caracterización ya clásica: la del militante sujeto a una disciplina férrea, antepuesta a toda atadura familiar. Esa madre, con sus altibajos, sus ataques de ira ante el menor desliz del secreto y la prohibición -una llamada telefónica del niño a una compañera de la que está enamorado- es a la vez la "madre loca", furiosa, que aparece en múltiples relatos, y esa otra capaz de mostrar su ternura en los momentos de calma cotidiana. Momentos especialmente trabajados en el film, para balancear la imagen de zozobra perpetua que ha quedado como un estereotipo. Es una película sobre el amor, dirá el director, que intenta "esquivar la idealización o el juicio, encontrar un lugar justo, de respeto y libertad, una exacta

\footnotetext{
${ }^{6}$ Esa infausta decisión de la dirigencia de Montoneros -el grupo militante/guerrillero más numeroso- hizo que retornaran al país, clandestinamente, cantidad de militantes que se habían exiliado, para una batalla contra la dictadura que nunca se dio, y donde la represión cobró, por el contrario, gran cantidad de víctimas.
} 
valoración de lo que fue -a su juicio- la última generación lírica”. Preguntado sobre el lugar de este film en su obra responderá, quizá inadvertidamente, con un performativo explícito: "Siempre supe que algún día iba a hacer mi infancia", un enunciado que puede tomarse a carta cabal.

El premio, por su parte, nos enfrenta a un paisaje de invierno desolado, una playa desierta donde Cecilia, una niña también de 7 años, vive con su madre en una casilla donde se guardan sombrillas y reposeras herrumbradas, con un mar encrespado a los pies y un viento persistente que adquiere por momentos un rol protagónico. Casi no hay palabras entre madre e hija, en una escena de despojo, unos pocos enseres indispensables para la supervivencia y un corte rotundo con el exterior. De a poco se advierte que el silencio traduce el ocultamiento, la huida de un peligro que ya se ha cobrado la vida de un familiar. Un padre ausente -como en La casa...- del que no se sabe siquiera si está vivo y la interdicción de hablar, de contar, de revelar la verdadera identidad cuando la nińa comienza a ir a la escuela y sobrevienen las preguntas lógicas: qué hace tu papá, dónde está, cómo se llama. A diferencia de las otras madres -la de Juan/Ernesto que maneja armas, la de Laura, que pasa sus días en la rotativa clandestina imprimiendo el periódico- la de Cecilia sólo arma pequeñas esculturas con caracoles, cuya inutilidad traduce el tiempo muerto, la soledad, el simple pasar. Una madre cuya depresión le impide incluso ocuparse de las cosas más elementales de su hija y que alterna el silencio con la ira ante cada infracción a la regla, que también aquí hay que hacerse perdonar. El nudo narrativo se centra en el premio que gana Cecilia por una composición escrita para un concurso organizado por los militares, que debe ir a recibir al colegio de manos de ellos en un acto especial, hecho que resulta insoportable para la madre y pone en tensión la presencia misma de ambas en el lugar.

En los tres casos la escuela se torna un territorio de riesgo, el acecho de la pregunta incontestable, el peligro del descubrimiento;

Desde ahora viviremos en la clandestinidad". Esto es exactamente lo que dice. Yo escucho en silencio. Entiendo todo muy bien, pero no pienso más que en una cuestión: la escuela. Si vivimos escondidos ¿cómo voy a hacer para ir a clase? (ALCOBA, 2010: 9)

Una experiencia cotidiana, de aristas traumáticas, donde se debe estar atento a todo, responder a otro nombre o no tener apellido: "Laura: esa es la única parte de mi nombre que me dejan conservar” dirá la niña de La casa de los conejos, y "Ernesto" no sabrá siquiera que es a él a quien le cantan el "Feliz cumpleaños" según la fecha de su documento falso. 
Esta infancia común, abrumada por la carga del secreto y del lenguaje fuera de edad, sometida a exigencias imposibles y conductas penalizables en las tres ficciones los nińos tienen que pedir perdón por "portarse mal", es decir, haber infringido las normas de seguridad o el secreto- pone en escena también, de modo contrastivo, semejanzas y diferencias en los personajes de las madres -los padres están ausentes o en un rol definido más bien por su responsabilidad en la organización, como en Infancia clandestina. No es irrelevante la cuestión por cuanto la decisión de continuar viviendo con los hijos y llevarlos incluso a algunas de sus actividades a sabiendas de los riesgos que corrían - una vez Diana lleva a Laura en la camioneta al reparto del periódico- es uno de los aspectos que ha suscitado las mayores críticas en cuanto a la militancia clandestina. Una escena nodal de esta última película muestra justamente la tensión dramática entre la madre y la abuela, que pide hacerse cargo de los niños en la elemental lógica del sentido común. Sin embargo, el personaje de la madre de El premio es quizá pionero en cuanto a mostrar la antítesis de un perfil heroico, la desolación en la que transcurrieron muchas vidas en las distintas variantes del exilio interior, el "insilio", como se dio en llamar. ${ }^{7}$ En cierto modo hay, en las tres ficciones, un intento de "entender sin entender o entender al revés", como dice la niña Laura, que supone también, sobre todo en Infancia, entender la intensidad de la esperanza, ese momento en que se creía todavía posible una transformación radical del estado de las cosas.

Benjamín Avila enfatiza ese tratar de entender el lugar del otro, el "porqué nos hicieron esto", aludiendo en particular al infausto desenlace de su película en el cual la casa es asaltada, sus moradores resisten ante los ojos espantados de Juan detrás de su escondite -la estructura del comic, que juega aquí el mismo papel de los muñequitos Playmobil en Los Rubios, pone en escena la violencia, lo intratable-, él mismo es secuestrado, interrogado y dejado finalmente a la puerta de la casa de su abuela mientras su hermanita en la ficción es apropiada y entregada a otra familia. Un modo de narrar la propia historia, en la cual su hermano menor también fue apropiado y recuperó su identidad en 1984, uno de los primeros nietos recuperados. "Nunca creyeron que irían a hacerle eso a los hijos", afirmará en alguna entrevista, reiterando algo de lo ya escuchado en la ímproba tarea de encontrar explicación lógica a un tiempo dislocado.

Más allá del valor intrínseco de estas obras -la de Alcoba es una novela de aliento poético, los dos films, ambos operas primas como largometrajes, están

\footnotetext{
${ }^{7}$ Paula Marcovitch, a los 8 ańos, fue efectivamente a vivir con su madre en San Clemente, una playa cercana a Buenos Aires, donde se filmó la película, mientras su padre, artista plástico, estaba en otra parte en "exilio interior". Ambas tomaron luego la opción de viajar a México, donde desarrolló su carrera de cineasta.
} 
muy logrados, cada uno en su género, Infancia es una producción que apunta a circuitos de gran público mientras que El premio es una película de autor, atenta al proceso de su realización y a los circuitos escogidos para su promoción- ${ }^{8}$ lo que me interesa aquí, en una lectura sintomática, es la temporalidad de su emergencia -ese "estado de memoria" que traducen- y el modo en que cada una pone en escena algo de lo cual poco se ha hablado hasta ahora: la vida cotidiana en dictadura, no sólo la de esos personajes arrastrados por una "locura" revolucionaria sino también ese trasfondo de miedo que involucró a la sociedad entera, quizá inadvertidamente para algunos, y que acompañó como una sombra la normalidad en un estado de excepción.

En primer lugar, la convivencia bajo un mismo techo del arsenal y la vida familiar, la trama de vigilancia, engańo y secreto que envuelve la cotidianidad de la militancia bajo la amenaza represiva del Estado, no habían sido abordadas hasta ahora del modo en que lo hacen La casa de los conejos e Infancia clandestina: desde los ojos de la infancia y desde la propia experiencia. Un tema espinoso, quizá poco conocido para vastos sectores, en especial ese "gran público" al cual apunta la película -que no por ello atenúa su valor político. El impacto en la audiencia -más perceptible en el caso del filmmuestra efectivamente una capilaridad en la recepción que quizá no existía años atrás y también, una vez más, la potencialidad de la ficción para aportar a la elaboración colectiva de las memorias del pasado. Cabe acotar que El premio -que obtuviera el Oso de Plata en la Berlinale de 2011 representando a México, donde vivía la autora, con muy buena recepción del público en distintos países- recién se ofreció en una sesión de pre-estreno en Argentina en el ámbito del Museo de la Memoria (ex Esma). ${ }^{?}$

Por otra parte, la normalidad suponía entre otras cosas el disciplinamiento de la vida cotidiana y de la infancia desde la escuela -cada una a su manera las tres ficciones dan cuenta de ello-, la escuela como un lugar clave en el afianzamiento del proyecto cultural de la dictadura, que era más sólido

\footnotetext{
${ }^{8}$ En un contacto con la directora, Paula Markovitch, cuya película fue producida en México y filmada en la Argentina, nos decía: "creo que un film no es sólo lo que se ve en una pantalla sino también los procesos creativos y tal vez, también la manera en que se exhibe y difunde es parte de la obra misma...la manera en la que se "hizo" El premio y la manera en que intenté concebir su promoción... ha sido muy importante para mí. Por ejemplo la proyección en el museo de la Memoria [el Centro Cultural Haroldo Conti, en Buenos Aires] me pareció fundamental para la obra”. (15/9/2013)

${ }^{9}$ El Museo funciona en un extenso predio de 17 hectáreas, en un barrio acomodado de Buenos Aires, donde funcionaba la Escuela de Mecánica de la Armada (ESMA) y donde, aparte de las actividades "normales" de formación de cadetes y despliegue militar, se encontraba el mayor campo de concentración y exterminio de la Argentina, que incluía una maternidad clandestina. En 2003 fue expropiado y transformado en lugar de memoria, que alberga distintas organizaciones de derechos humanos, el Archivo Nacional de la Memoria y el Centro Cultural Haroldo Conti, además de un Museo dedicado a la Memoria de la guerra de las Malvinas.
} 
de lo que podría pensarse. Sobre ese proyecto y su relevancia en la escala de las transformaciones que el llamado "Proceso de Reorganización Nacional" -autodenominación de la dictadura- se sentía llamado a realizar, da cuenta el estudio que mencionamos al comienzo sobre la revista infantil Billiken, material de apoyo escolar y entretenimiento durante generaciones -fue fundada en 1919 y continúa saliendo hasta hoy, con su frecuencia semanal- un estudio que muestra la profunda complicidad del medio -la Editorial Atlántida-con los objetivos de la dictadura en cuanto a la instauración de un orden unívoco de valores basados en la obediencia, el respeto a la tradición, la autoridad y la disciplina; la existencia de un mundo regulado, sin conflictos; la exaltación de la técnica y la modernización -afines a las políticas neoliberales en cursoy en un rango no menor, la representación de las fuerzas militares en roles abnegados, de ayuda y defensa de los intereses nacionales y de la soberanía. ${ }^{10}$

"Los militares de Billiken -afirma Paula Guitelman- premian a los alumnos (como nos lo muestra El premio). Ser tiernos y obedientes no les impide ser al mismo tiempo valientes, sacrificados y viriles, prestan su colaboración en campos que no son los propios, siempre pensando en el beneficio común." (GUITELMAN, 2007:115)

Hasta aquí (auto) figuraciones de infancia -o ficciones autobiográficasque nos proponen repensar el tiempo que fue desde un hoy que condiciona la mirada -los tres autores asumen conscientemente ese lugar de enunciación, que entraña tanto la necesidad de comprensión como de hacer justicia a su propio pasado. Laura Alcoba dirá, por ejemplo en su prólogo: "si al final hago este esfuerzo de memoria para hablar de la Argentina de los Montoneros, de la dictadura y del terror, desde la altura de la niña que fui, no es tanto por recordar sino por ver si consigo, al cabo, de una vez, olvidar un poco" (op. cit.: 7). Paula Markovitch por su parte escribe en un mail: "Creo que no es casual que surjan muchas obras en torno a la infancia en dictadura, ya que los que fuimos nińos en esos años, tenemos la edad para procesarlo y contarlo”.

¿Pero qué ocurriría si pudiéramos asomarnos a otras figuraciones de infancia, a otras voces, no ya ficcionales sino "verdaderas", de nińos cuando fueron niños y que por lo tanto responderían de otro modo a la pregunta del comienzo ¿Quién habla allí?

Esa aventura fascinante -y desgarradora- es lo que nos propone el libro de Hugo Paredero que mencionamos al principio y que completa nuestro

\footnotetext{
${ }^{10}$ El análisis, desde una perspectiva de crítica cultural, abarcó dos años emblemáticos durante el período dictatorial, 1977 y 1978, ańos de intensa violencia represiva en los que también tiene lugar el Mundial de fútbol. El propósito, según la autora, era indagar el tipo de subjetividad infantil y el ideal de niñez que la revista conformó en el plano discursivo y su estrecha relación con los valores imperantes.
} 
corpus: voces de 150 niños de 5 a 12 años, que han vivido parte de su infancia en dictadura y hablan de ella recién llegada la democracia, es decir, con el recuerdo vívido en los ojos y una increíble libertad en las palabras. Niños de distintas regiones, clases sociales y orientaciones familiares, algunos de ellos -21 - con padres desaparecidos. La entrevista tiene sólo algunas preguntas abiertas, indicativas, y las respuestas -con la extensión que cada uno quiso darle-se ordenan según esas líneas temáticas. Para dar sólo algunos ejemplos:

\section{Sobre los señores con gorra que se pusieron a gobernar...}

Me gustan los militares, y los premios que les dan. Me gusta que ellos siempre reciben medallas en su honor por defender a la Patria. [Héctor F. Vega, 10 años] (Paredero, op.cit:18)

Secuestraban a la gente y les hacían cosas feas. También a un tío mío le hicieron lo mismo. Yo tenía mucha bronca porque pasaba todo eso y era chiquito. ¿Pero la gente grande que tenía bronca qué hacía para que se fueran los militares? [Pablo G. Aguila, 10 años] (Ibíd:18)

No sé qué contestar...Todavía no me enseñaron en la escuela una gran explicación de los señores con gorra. [Lionel Mendiz, 9 años] (Ibíd:21)

No me gustan los militares, son malos, entran a las casas y matan a la gente...o los desaparecen, como a mi papá. [Ernesto Ringa, 8 años] (Ibíd.: 23)

Estoy pensando...Porque mi mamá no me cuenta tanto, entonces yo no sé mucho... ¿Esos señores de gorra no serán los que ordenaban que se lleven a las personas y las hagan desaparecer? [Juan María Cruz, 5 años] (Ibíd: 21)

Hicieron todo lo más feo que pudieron. Con ellos todo se convirtió en miedo. [Federico Báez, 10 años] (Ibíd.:22)

\section{Cuando la gente comenzó a olvidarse del mundial (1978)... ${ }^{11}$}

La gente se preocupaba porque la plata no alcanzaba y cada vez más no podían darse todos los gustos. Por suerte, las familias podían conservar todavía su cariño. [Gabriela Wyczykier, 11 años] (Ibíd.: 42)

No podía alcanzar la plata porque los gobernadores eran todos hombres y los hombres siempre gastan mucha más plata que las mujeres. [Daniela Ledesma, 10 años] (Ibíd.; 43)

La gente se empezó a dar cuenta de que les querían hacer el mal y empezaron las reuniones en las calles, empezaron a tirar piedras al gobierno, todas esas cosas. También la policía se defendía con gases lacrimógenos. Y después mataron a

\footnotetext{
${ }^{11}$ El Mundial, que ganó Argentina y que despertó gran entusiasmo en un país de larga tradición futbolística, fue utilizado por la dictadura como un acercamiento popular, sustentado por consignas chauvinistas.
} 
mucha gente. Yo he visto en la televisión que venían corriendo los militares y había una casa que la bombardearon, la ametrallaron, y ellos después salieron disparando sin que nadie los persiga. [Ignacio La Fuente, 9 años] [Ibíd.; 43) ${ }^{12}$

\section{Sobre lo que se conversaba en la casa...}

Hablaban de los árboles, de las flores, de que hacía mucho frío y caía nieve, del amor, de la gente que se moría, de aviones, de helicópteros, de autos, de micros, de comidas, del arbolito de navidad y también de sillones...[Malena Martín, 5 años] (ibíd.: 74)

Charlaban de que los hijos ya eran grandes y se iban al servicio militar y entonces la gente dejaba de charlar y lloraba, porque a veces los hijos se mueren.[Rafael E. Armendáriz, 8 años] (Ibíd.:78) ${ }^{13}$

Conversaban de los desaparecidos, como en el caso de mi papá. Que no sé, él pensaba de una forma y un día lo agarraron y lo metieron en un auto y no sé dónde lo llevaron...Ahora nos enteramos, pasaron todos estos ańos hasta que yo fui grande, y después mi mamá me contó que lo habían matado, pero no sé quien lo mató, lo mataron en otro lugar, no lo mataron acá.(...). Cuando pienso tengo una sensación triste, pero bueno, ya pasó y no hay nada que hacer. [Camilo Moncalvillo, 9 años] (Ibíd.:82)

\section{Sobre la palabra desaparecidos...}

¿Alguna vez podrán encontrarlos a esos chicos, a esos padres, a toda esa gente que está desaparecida? ¿Por qué no pueden volver a su casa, porque no conocen el camino o porque se los hicieron olvidar? [Mónica Martín, 8 años] (Ibíd.: 184)

Una vez, cuando yo era chico, mi mamá no sé lo que estaba haciendo y mi papá tampoco...Estábamos mirando la tele, y después no sé qué le pasó a mi hermana, gritaba mi hermana, y no sé donde estaba mi mamá y vino una amiga y se fue y después vinieron los que la secuestraron, y mi hermana le preguntó a los hombres qué hacían con los revólveres y los hombres le dijeron que jugando al policía y al ladrón, mi hermana me lo contó. [Pedro Marín, 7 años] (Ibíd.: 17)

De eso sé que a mi prima le ha desaparecido su mamá y su papá. A mí, mi papá, y no sabemos dónde está. A mi papá lo han llevado preso y después lo han matado, pero todos los días mi mamá sale a averiguar si está vivo. [Andrés Gómez, 8 años] (Ibíd.: 191)

\footnotetext{
${ }^{12} \mathrm{Y}$ hasta es posible -sin forzar la hipótesis- que la casa bombardeada que el niño recuerda haber visto en la televisión haya sido la "Casa Anahi" retratada en el libro de Laura Alcoba.

${ }^{13}$ Las referencias a la muerte en este capítulo remiten también a la guerra de las Malvinas (1982), que la dictadura libró contra el Reino Unido por la supuesta recuperación de esas islas del Atlántico Sur históricamente reivindicadas como argentinas, que respondió prioritariamente a una estrategia de afianzamiento del régimen, ya muy desacreditado, y cuya derrota, en una vergonzosa capitulación, aceleró su fin.
} 
Hugo Paredero, periodista y conductor de radio, recogió estos relatos durante 1984, en el primer año de la reciente democracia, armó el libro y trató durante largo tiempo de encontrar editor, sin éxito. Todos lo consideraban muy interesante pero no se atrevían a publicarlo. Algunos, porque consideraban que las heridas estaban aún abiertas, y más tarde, porque estarían cicatrizando y no convenía recordar... Hasta que una vez -como en los cuentos de hadas- unos hermanos que escuchaban la radio mientras trabajaban encontraron su voz muy familiar y creyeron reconocer en ella a quien les había hecho una entrevista bastante singular cuando eran niños, veintitrés años antes... Lo llamaron y resultó algo de un orden casi mágico: eran dueños de una editorial, el Zorzal, y la publicación, que sucedió en 2007, les pareció una tarea irrenunciable.

Se cruzan así en la trama de mi corpus, en una evidente sintonía narrativa, voces distantes en tiempo y lugar que sin embargo hablan de lo mismo. Quizá esa sintonía atestigüe de la pertinencia de haberlas convocado. Pero es la concepción dialógica bajtiniana, que aúna respuesta y responsabilidad, la que nos ayuda a comprender que esas voces responden, cada una a su modo, a la inquietud memorial que dejó como impronta ese pasado. Una inquietud que no se agota en este pantallazo - hablando de cine- sino que deja afuera un "exterior constitutivo", según la clásica expresión, cara a Derrida- otras memorias en conflicto en una sociedad que -como todas- dista de ser una totalidad reconciliada.

Quizá este "estado de memoria" diga, en la conmemoración de los 40 años del golpe y a 33 años del retorno a la democracia, que hemos alcanzado la madurez suficiente para poder hablar de lo acontecido en múltiples registros, más allá de la "infancia" (AGAMBEN, 2007) y también sobre la infancia, aunque las heridas no hayan cicatrizado del todo y muchas queden abiertas sin remedio, como el abismo de lo trágico. Sin embargo, en el país del Nunca Más, donde en buena medida se ha dado cumplimiento al mandato ético de verdad y justicia, siguen pendientes innúmeras preguntas que quizá nunca podamos responder.

\section{Referencias}

AGAMBEN, G. Infancia e historia. Buenos Aires: Adriana Hidalgo, 2007.

ALCOBA, L. La casa de los conejos. Buenos Aires: Edhasa, 2010.

ARFUCH, Leonor. El espacio biográfico. Dilemas de la subjetividad contemporánea. Buenos Aires: Fondo de Cultura Económica, 2002.

. Memoria y autobiografía. Exploraciones en los límites, Buenos Aires: Fondo de Cultura Económica, 2013.

AVILA, B. Infancia clandestina. film, Dirección y libro, 2011. 
BAJTÍN, M. Estética de la creación verbal. México: Siglo XXI, 1982.

BENJAMIN, W. Infancia en Berlin hacia 1900. Barcelona: Taurus, 1990.

GADAMER, H. Verdad y método. Salamanca: Sígueme, 1977.

GUITElMAN, P. La infancia en dictadura. Buenos Aires: Prometeo, 2006.

MARKOVITCH, P. El premio, film México: 112 m. Dirección y libro, 2011.

PAREDERO, H. ¿Cómo es un recuerdo? Buenos Aires: Libros del Zorzal, 2007.

RICOEUR, P. La memoria, la historia, el olvido. Buenos Aires: Fondo de Cultura

Económica, 2004.

Leonor Arfuch é Doutora em Letras pela Universidad de Buenos Aires. Atualmente é professora e investigadora nessa universidade. Foi professora convidada na Universidade de Essex (Inglaterra); na UNAM e na Universidade Ibero-americana (México); na Universidade Católica e na Universidade Diego Portales (Chile); na Universidade de Stanford (USA) e na UERJ (Brasil). Obteve o British Academy Professorship Award (2004) e uma bolsa Guggenheim (2007). É autora de El espacio biográfico, Dilemas de la subjetividad contemporánea (2002, segunda ed. 2005), O Espaço Biográfico - Dilemas da Subjetividade Contemporânea (Tradução ao português de Paloma Vidal, 2010), Crítica cultural entre politica y poética (2008) e Memoria y autobiografía. Exploraciones en los límites (2013).

E-mail: larfuch@yahoo.com.ar 